\title{
Suicidal Hanging in Eskisehir, Turkey: 25 Year Analysis \\ Karbeyaz $\mathbf{K}^{1^{*}}$, Celikel $\mathbf{A}^{2}$ and Balci $\mathbf{I}^{1}$
}

${ }^{1}$ Department of Forensic Medicine, Eskişehir Osmangazi University Faculty of Medicine, Eskisehir, Turkey

${ }^{2}$ Department of Forensic Medicine, Mustafa Kemal University Faculty of Medicine, Hatay, Turkey

Corresponding author: Karbeyaz K, Department of Forensic Medicine, Eskişehir Osmangazi University Faculty of Medicine, Eskisehir, Turkey, Tel: + 905052230885; Email: drkenankarbeyaz@hotmail.com

Received date: August 21, 2017; Accepted date: August 26, 2017; Published date: August 31, 2017

Copyright: ( 2017 Karbeyaz K, et al. This is an open-access article distributed under the terms of the Creative Commons Attribution License, which permits unrestricted use, distribution, and reproduction in any medium, provided the original author and source are credited.

\begin{abstract}
In this study, it was aimed to evaluate the autopsy findings of deaths due to hanging in the last 25 years in Eskisehir province located in western Anatolia and to share them in the literature. The gender, age, scene of crime, the material used for hanging type and hanging, autopsy findings and toxicological findings were examined using the data of Eskişehir Forensic Medicine Branch Directorate and judicial investigation files in that period. It was determined that hanging cases have increased in the recent years. $65.1 \%$ of the cases were male $72.1 \%$ of the cases were typical hanging. Hanging cases can only be solved by the collective work of crime scene investigators, police officers, prosecutors and doctors.
\end{abstract}

Keywords: Hanging; Suicide; Eskisehir

\section{Introduction}

Hanging is a fatal event that occurs as a result of the fact that the body weight squeezes the neck region using a rope or similar material $[1,2]$. In fact, death usually develops in the form of cerebral ischemia that develops as a result of pressure on trachea and neck veins or sometimes in the form of reflex heart arrest due to vagal inhibition caused by pressure of the carotid sinus. In hanging, these mechanisms should not be considered separately [1-5]. Hanging is known as the most frequently used method of suicide worldwide [3-14]. It has been reported that about 2000 suicide deaths due to hanging occurs per year in England [15]. It has been reported in the studies conducted all over the world that the incidence of hanging is gradually increasing [3, 16-21]. Hanging is thought to be the most commonly used suicide method as hanging material can be easily found and the hanging action can be performed almost everywhere $[1,9,11,22]$.

In hanging autopsies, detailed crime scene investigation, forensic investigation and findings should be evaluated together [3-5]. Neck region should be examined in detail during autopsy. Hemorrhage and ecchymoses in soft tissues under neck skin, ecchymotic fractures in hyoid bone and troit cartilage support that hanging has been performed while the person is alive $[2,3,16,17,22-26]$. Whether the person was affected by a substance or alcohol at a level that could make him/her ineffective before death should be investigated by performing toxicological examination [2,27-29]. In this study, it was aimed to evaluate the autopsy findings of deaths due to hanging in the last 25 years in Eskisehir province located in western Anatolia and to share them in the literature.

\section{Material and Method}

The study was carried out in Eskişehir province located in western Anatolia. The cases that were determined to die as a result of mechanical asphyxia due to hanging in the 25 -year period between
1992 and 2016 in Eskişehir were included in the study. The gender, age, scene of crime, the material used for hanging type and hanging, autopsy findings and toxicological findings were examined using the data of Eskişehir Forensic Medicine Branch Directorate and judicial investigation files in that period. Investigation files include the details about autopsy and crime scene investigation, photos, the statements of the relatives and family of the deceased person and witnesses, the reports of social workers and the examinations specially performed for the cases. In our department where the study was performed, crime scene investigation findings, investigation findings of police officers, statements of the relatives of the deceased person and all evidence of the investigation in judicial deaths are evaluated and then autopsy is performed. In the investigation files, it was concluded that all of the cases committed suicide and the files were closed. The data were evaluated using the SPSS 20.0 program.

\section{Findings}

It was determined that a total of 9813 autopsies were performed in Eskişehir during the 25 -year period covered by the study, and 872 $(8.9 \%)$ of them died because of suicide. $57.9 \%$ of suicide cases and $5,1 \%$ of all unnatural deaths occurred as a result of mechanical asphyxia due to hanging. It was found that the annual average of 20.2 deaths due to hanging occurred. It was determined that hanging cases have increased in the recent years. It was found that hanging cases occurred most frequently in $2016(\mathrm{n}=33,6.5 \%)$ and have been increasing every year (Graph 1).

It was determined that $329(65.1 \%)$ of the cases were male and 176 (34.9\%) of them were female. It was determined that the youngest of the cases was 15 years old and the oldest of them was 93 years old, the age average was $37 \pm 17.9$, and that the most common age group was 19-29 years (Graph 2). It was determined that 43 cases $(8.5 \%)$ were at the age of 18 , and 45 cases $(8.9 \%)$ were 65 years of age or older. The distribution of age groups by gender is presented in Table 1. It was found that there was no significant difference between age group and gender (Table 1) $(\mathrm{P}>0.05)$. 
Citation: Karbeyaz K, Celikel A, Balci I (2017) Suicidal Hanging in Eskisehir, Turkey: 25 Year Analysis. J Forensic Res 8: 388. doi:

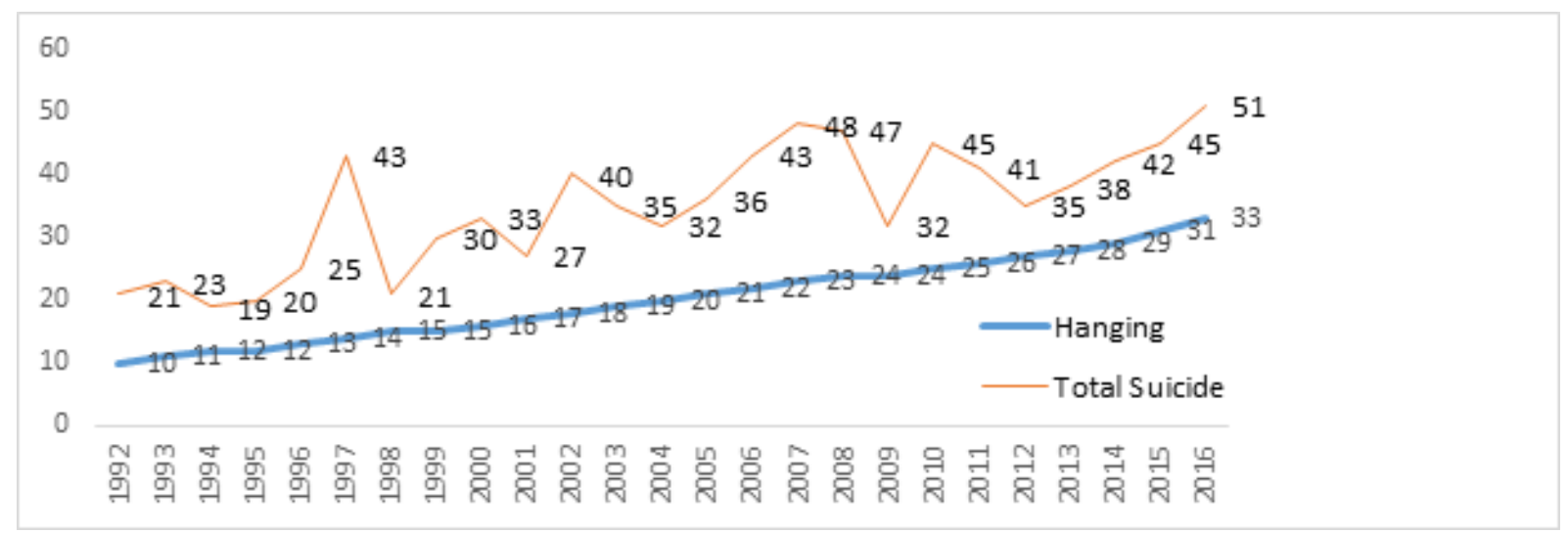

Graph 1: Distribution of all suicide and hanging cases by years.

\begin{tabular}{|l|l|l|l|l|l|l|}
\hline Age group & Male & & Female & & Total & \\
\hline & $\mathbf{n}$ & $\%$ & $\mathbf{n}$ & $\%$ & $\mathbf{n}$ & $\%$ \\
\hline $\begin{array}{l}18 \text { years and } \\
\text { below }\end{array}$ & 30 & 9.1 & 13 & 7.4 & 43 & 8.5 \\
\hline $19-29$ years & 103 & 31.3 & 59 & 33.5 & 162 & 32.1 \\
\hline $30-39$ years & 67 & 20.4 & 34 & 19.3 & 101 & 20 \\
\hline $\begin{array}{l}40-49 \text { years } \\
\text { 50-59 years }\end{array}$ & 46 & $14 . .0$ & 27 & 15.3 & 73 & 14.5 \\
\hline $\begin{array}{l}60 \text { years and } \\
\text { above }\end{array}$ & 43 & 12.2 & 24 & 13.6 & 64 & 12.7 \\
\hline Total & 329 & 100 & 176 & 100 & 505 & 100 \\
\hline X2=1.470 & $\mathrm{df}=5$ & $\mathrm{P}>0.05$ & & & & \\
\hline
\end{tabular}

Table 1: The distribution of age groups by gender.

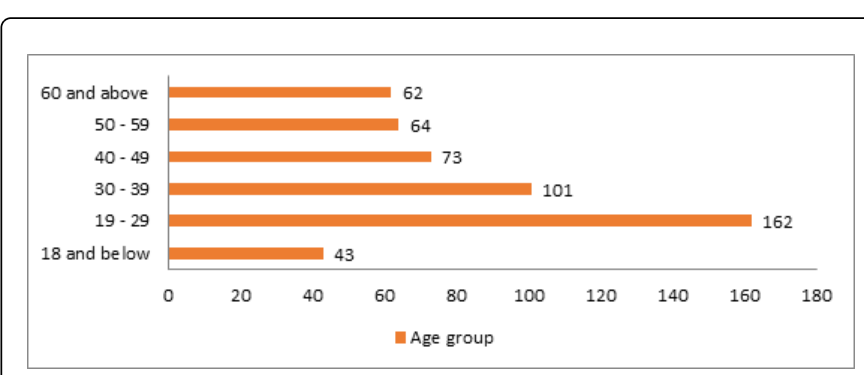

Graph 2: Distribution of cases according to age groups.

It was determined that the rope was most frequently used material $(\mathrm{n}=415,82.2 \%)$ as a hanging material, and secondly wire was used (3.2\%) (Table 2). All of the cases were determined to be suicide. It was determined that hanging was performed most frequently in house attachments $(\mathrm{n}=417,82.6 \%)$ and in workplaces as the second (Table 3$)$. It was determined that $364(72.1 \%)$ of the cases were typical hanging, $241(27.9 \%)$ of them were atypical hanging.

\begin{tabular}{|l|l|l|}
\hline Tools used for hanging & $\mathbf{n}$ & $\%$ \\
\hline Rope & 415 & 82.2 \\
\hline Wire & 16 & 3.2 \\
\hline Bed Lining & 14 & 2.8 \\
\hline Scarf /Cheesecloth & 14 & 2.8 \\
\hline Belt & 13 & 2.5 \\
\hline Electric Cable & 12 & 2.3 \\
\hline Bathrobe-Pyjama Belt & 9 & 1.8 \\
\hline Tie & 6 & 1.2 \\
\hline Water Hose & 4 & 0.8 \\
\hline Dog Collar & 2 & 0.4 \\
\hline Total & 505 & 100 \\
\hline
\end{tabular}

Table 2: Distribution of the tools used in the hanging method.

\begin{tabular}{|l|l|l|}
\hline Place of suicide & Total & $\%$ \\
\hline House and its attachments & 417 & 82.6 \\
\hline Workplace & 79 & 15.6 \\
\hline Prison & 5 & 1 \\
\hline Hotel & 3 & 0.6 \\
\hline Tree & 1 & 0.2 \\
\hline Total & 505 & 100 \\
\hline
\end{tabular}

Table 3: Distribution of the places of suicide.

According to the information obtained from the scene investigation findings, it was determined that $413(81.8 \%)$ of the cases were full hanging and 92 (18.2\%) of them were semi-hanging. Hanging telemesis was determined during external examination in all cases. The location of hanging telemesis is presented in Graph 3. It was found that hanging telemesis was located in above the thyroid cartilage in 479 
Page 3 of 5

(94.9\%) of the cases, at the over the thyroid cartilage in $21(4.1 \%)$ of them, and under the thyroid cartilage in $5(1.0 \%)$ of them (Graph 3$)$.

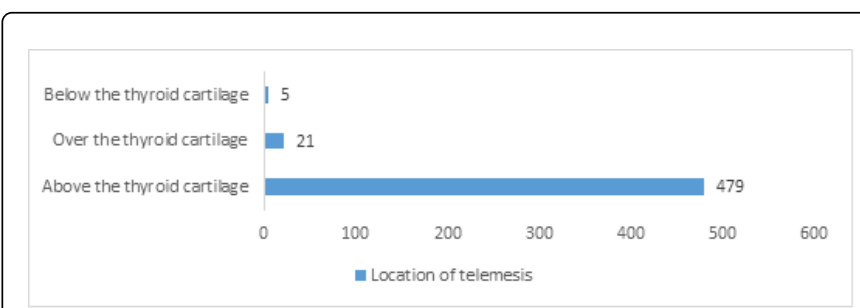

Graph 3: Distribution of hanging telemesis according to its location.

The internal findings detected during autopsy are presented in (Table 4). At least one internal examination finding was detected in each case. While hemorrhage or ecchymosis was detected in different sizes and depths under the skin of the neck in all cases, hemorrhage or ecchymosis $(n=74.5)$ was detected in the superficial muscles of the neck and soft tissues in 376 cases. The ecchymosed fracture was determined in the hyoid bone in $109(21.6 \%)$ of the cases, in the troit cartilage in $95(18.8 \%)$ cases and in both of them in $66(13.1 \%)$ cases. Vertebral fracture and medulla spinalis injury were found in 2 cases. It was determined that one of these cases was a 75 -year old woman and hung herself to the ceiling of a 15-meter high store, the other one was a 67-year-old man and he performed hanging from the roof of the workplace towards the elevator shaft. In the toxicological evaluation made, ethanol was found in the blood of 57 (11.3\%) of the cases. It was determined that the lowest ethanol content was $23 \mathrm{mg} / \mathrm{dl}$, the highest was $134 \mathrm{mg} / \mathrm{dl}$ (Table 5). Benzodiazepine (94-215 ng/ml), barbiturate $(57-103 \mathrm{ng} / \mathrm{ml})$ and amphetamine $(124 \mathrm{ng} / \mathrm{ml})$ were found in 5 cases, 2 cases and 1 case, respectively. Hanging cases are frequently encountered in forensic medicine practice. It is the most commonly used method of suicide all over the world [3-12].

\begin{tabular}{|l|l|l|}
\hline The finding determined during autopsy & $\mathbf{n}$ & $\mathbf{\%}$ \\
\hline Ecchymosis or hemorrhage under the skin of the neck & 505 & 100 \\
\hline $\begin{array}{l}\text { Ecchymosis or hemorrhage in the superficial muscles of } \\
\text { the neck }\end{array}$ & 376 & 74.5 \\
\hline Ecchymosed fracture in the hyoid bone & 109 & 21.6 \\
\hline Ecchymosed fracture in thyroid cartilage & 95 & 18.8 \\
\hline Ecchymosed fracture in hyoid and troit cartilage & 66 & 13.1 \\
\hline Fracture and medulla spinalis injury in the neck vertebrae & 2 & 0.4 \\
\hline
\end{tabular}

Table 4: Distribution of internal findings determined during autopsy.

\begin{tabular}{|l|l|}
\hline Ethanol content & $\mathbf{n}$ \\
\hline $0-50 \mathrm{mg} / \mathrm{dl}$ & 12 \\
\hline $51-100 \mathrm{mg} / \mathrm{dl}$ & 35 \\
\hline $101-134 \mathrm{mg} / \mathrm{dl}$ & 10 \\
\hline Total & 57 \\
\hline
\end{tabular}

Table 5: Toxicologic examination results.

\section{Discussion}

In the presented study, all hanging cases in the 25 -year period were suicides as a result of the investigation made. Murder and accidentoriginated hanging event was not encountered in our province during the study period. It is thought that the fact that hanging material can be easily found and the hanging action can be performed almost everywhere is the cause of the fact that hanging is the most common suicide method. It was determined that $5.1 \%$ of all judicial deaths were caused by hanging in Eskişehir during the study period. In a study conducted in Diyarbakır in our country, it was reported that $2.8 \%$ of judicial deaths were caused by hanging. In the study conducted in India by Rao et al., it was reported that 264 (3.31\%) 7968 autopsies performed between 2010-2013 were due to hanging [30]. This difference is thought to be due to regional differences and the changes in the ratio of suicide. According to the statistics of the year 2014 in our country, it was reported that the ratio of suicide was 4.07 per hundred thousand, Eskişehir was the fifth province with the highest ratio of suicide, and the ratio of suicide was 6.59 [31]. In the studies conducted on suicide, it was reported that men died more frequently due to suicide $[6,8,9,32-35]$. In the studies conducted in parallel to it, victims were reported to be males more frequently $[16,17,22,36,37]$. In a study conducted on hanging in Saudi Arabia, 86.46\% of the cases were reported to be male [18]. In the study conducted in Iran, $83 \%$ of the cases were reported to be male [13]. In the study conducted on hanging by Dean et al., the male/female ratio was reported to be 5.18 [37]. In the present study, it was determined that 329 (65.1\%) of the cases were male and $176(34.9 \%)$ of them were female in accordance with the literature.

In a study of a 33-year period that covered 1979-2012 in Istanbul, $53.1 \%$ of the hanging cases were between 19-41 [17]. In the study conducted by Kurtuluş et al., the mean age of the hanging cases was reported to be 40.9 [35]. In a study conducted in Kuwait, it was reported that hanging cases occurred most frequently in the third decade [22]. In the present study, in accordance with the literature, it was determined that the mean age of the cases was $37 \pm 17.9$, it was most frequently and secondly seen between 19-29 (32.1\%) and 30-39 (20\%) respectively. These ages are known as the most common age range in studies related to suicide [6-9,11]. According to the data of the Turkish Statistical Institute (TSI), it has been reported that suicides are most commonly seen in the 15-24 age group (25.6\%) and then in the 25-34 age group (19.2\%) in our country [34]. In a study conducted in India, half of the hanging cases were reported to be between 21 and 30 years of age [3]. In the study conducted in Istanbul by Üzün et al., it was found that hanging cases were most frequently seen between the ages of 20-29 [3].

The hanging material used may vary according to the person's environment and conditions. However, it has been generally reported in studies conducted on hanging that the rope has been used most frequently $[3,10,17,22,39,40]$. In the study conducted by Ambade et al., rope has been used in hanging cases by the ratio of $67.7 \%$ [39]. In the study conducted in İstanbul, it was reported that rope was used in $85.68 \%$ of the cases [3]. In the present study, it was determined that rope was used as the hanging material in $82.2 \%(n=415)$ of the cases. It was determined to be followed by wire, bed lining, scarf and belt. In the studies conducted on hanging, it was reported that the cases committed suicide most frequently at home $[3,17,22,40]$. In the study conducted by Üzün et al., it was determined that $83.31 \%$ of the hanging cases were at home [3]. In the study conducted by Gören et al. in Diyarbakır, it was determined that $73.6 \%$ of the hanging cases were 
at home [10]. In the present study, in accordance with the literature, it was found that hanging was most frequently performed in house and its attachments $(\mathrm{n}=417,82.6 \%)$ and then in workplaces.

The fact that the knot of the hanging material is at back of the neck is called typical hanging $[1,2,41]$. In a study conducted in the province of Denizli in Turkey, $52.9 \%$ of the hanging cases were reported to be typical hanging [35]. In the study conducted in Samsun by Aydin et al., $82 \%$ of the hanging cases were found to be typical hanging [42]. In a study conducted in Diyarbakır, $60.7 \%$ of the hanging cases were reported to be typical hanging [10]. In the present study, it was determined that $72.1 \%$ of the cases were typical hanging according to literature. The hangings in the form that the body does not touch anywhere are called full hanging $[1,13,41]$. In the literature related to hanging, it is reported that full hanging is most frequently encountered $[23,25,30,42]$. In the study conducted in Samsun, it was reported that $77.1 \%$ of the cases were full hangings [42]. In a study conducted by Rao and his colleagues in India, it was reported that $88 \%$ of the cases of hangings were full hangings [30]. In the study conducted by Sharma et al. this ratio was $68 \%$ [23]. In the present study, 413 of the cases $(81.8 \%)$ were determined as full hangings based on the data obtained from the crime scene investigation records.

In the toxicological examination, ethanol was detected in the blood in 57 cases (11.3\%). The lowest ethanol content was $23 \mathrm{mg} / \mathrm{dl}$ and the highest was $134 \mathrm{mg} / \mathrm{dl}$. Amphetamine $(124 \mathrm{ng} / \mathrm{ml})$ in 1 case, benzodiazepine $(94-215 \mathrm{ng} / \mathrm{ml})$ in 5 cases and barbiturate (57-103 $\mathrm{ng} / \mathrm{ml}$ ) in 2 cases were also found. In a study conducted in Istanbul, alcohol was detected in $15.3 \%$ of the cases [17]. In the study conducted by Üzün et al. alcohol was found in $11.9 \%$ (3) of the hanging cases and in another study in Saudi Arabia the ratio was 6.76\% [18]. The level of the alcohol and other hypnotic drugs found in the blood is important due to whether it will leave the person inactive. In the present study, the amount of alcohol detected was not at a level that would make them inactive. The detected active drug substances are determined to come from the drugs they use on a regular basis. This was also supported by the findings of the crime scene and the investigation.

In hanging cases, it is known that hanging mark is usually on the upper part of the thyroid cartilage [1,2]. In the present study, according to the external examinations, hanging mark was detected in all the cases. In 479 cases (94.9\%), the mark was located in the upper part of the thyroid cartilage. In 26 cases in which hanging mark was in the thyroid cartilage line or below, along with criminal investigation and evidence, it was determined that the incident was a suicide by hanging. In a study conducted by Rao in India, hanging mark was found above/at the top of the thyroid cartilage in $82.58 \%$ of the cases [30]. In hanging autopsies, ecchymosis under the skin and soft tissue bleeds in the neck region; echogenic fractures, vertebral fractures and medulla spinalis injury in hyoid bone and thyroid cartilage can be seen. The materials used, the age of the person, whether or not it is a full hanging, and the hanging distance are affecting the formation of these findings. [1-3,5,16,19-21,23,26,37,43]. These findings support the fact that the act of hanging takes place when one is alive $[1,2,21,23,24,26]$. In the study conducted in Istanbul, lesions were found under the skin or in soft tissues in all cases [17]. Also in the present study, hemorrhage or ecchymosis was found under the neck skin in all cases, and hemorrhage or ecchymosis $(n=74.5)$ in the surface muscles and soft tissues of the neck in 376 cases. In a study conducted in Kuwait, bone fractures in the neck region were reported in $44.07 \%$ of the hanging cases [22]. In the study of Sharma et al. in India, $44.9 \%$ of the cases were found to have a bone fracture in the neck region [23]. In the study conducted by Üzün et al., hyoid bone fractures were found in $23.2 \%$ and thyroid cartilage fractures in $21.4 \%$ of the cases [3]. In this presented study, fractures with ecchymosis were detected in hyoid bone in 109 cases $(21.6 \%)$, in thyroid cartilage in 95 cases $(18.8 \%)$ and the both in 66 cases $(13.1 \%)$. Vertebral fracture and medulla spinalis injury were identified in 2 cases $(0.4 \%)$. One of these 2 cases was a 75 years old-woman hung herself on the roof of a 15-meter-high depot, while the other was a 67-year-old man hang himself from the roof to the elevator shaft in his workplace. In a study conducted in India, it was reported that there were vertebral fractures in $1.6 \%$ of the hanging cases [25]. Vertebral fractures may occur in primordial executions and at very high distances $[1,2,25]$. Vertebral fractures may occur in the executions of death penalty and in hangings exercised at very high distances [1,2,25]. Also, in the 2 cases with vertebral fractures mentioned above, the hanging distance were high and both were oldaged.

As a conclusion, 505 people has commited suicide by hanging method in our city in the past 25 years. Ratio of hanging cases over all suicide cases are determined as $57.9 \%$ also ratio of hanging cases over all unnatural caused death are determined as 5.1\%. It's stated that most of the suicide cases in our city are hanging cases. Autopsy findings and demographical features of hanging cases are found as compatible with literature. It is thought that it would be meaningful if as the most frequent suicide cases in our city, the data of hanging cases has been shared with the literature [42].

Hanging cases can only be solved by the collective work of crime scene investigators, police officers, prosecutors and doctors. In the present study, it was seen that this team worked together and contributed to the investigation in all of the cases [43]. In the study, after detailed investigation and evidence collection, it was decided that all cases were an act of suicide. It appears that the data obtained are consistent with the literature. It has been determined that the number of hanging cases is increasing every year.

\section{References}

1. Shkrum MJ, Ramsay DA (2007) Forensic pathology and trauma: Asphxia. Springer Science \& Business Media, New Jersey, USA.

2. Saukko P and Bernard K (2015) Knight's forensic pathology. (4th edtn), CRC Press, Florida, USA.

3. Uzün I, Büyük Y, Gürpinar K (2007) Suicidal hanging: Fatalities in Istanbul retrospective analysis of 761 autopsy cases. J Forensic Leg Med 14:406-409.

4. Demirci S, Dogan KH, Erkol Z, Gunaydin G (2009) Ligature strangulation deaths in the province of Konya (Turkey). J Forensic Leg Med 16: 248-252.

5. Azmak D (2006 ) Asphyxial deaths: A retrospective study and review of the literature. Am J Forensic Med Pathol 27:134-144.

6. Azmak AD (2006) Suicides in Trakya region, Turkey, from 1984 to 2004 Med Sci Law 46:19-30.

7. Coskun M, Zoroglu S, Ghaziuddin N (2012) Suicide rates among Turkish and American youth: A cross-cultural comparison. Arch Suicide res 16: 59-72.

8. Metin A, Cileli G, Koçar I, Dokgoz H (2014) The sociodemographic Characteristics of suicide cases in Mersin. Adli Tıp Bülteni 19: 49-52.

9. Karbeyaz K, Akkaya H, Balcı Y (2013) Analysis of suicide deaths in a 15year period in Eskisehir, Western Anatolia, Turkey and the determination of risk factors. Ann Saudi Med 33: 377-382.

10. Goren S, Subasi M, Tirasci Y, Ozen S (2004) Female suicides in Diyarbakir, Turkey. J Forensic Sci 49: 796-8. 
Citation: Karbeyaz K, Celikel A, Balci I (2017) Suicidal Hanging in Eskisehir, Turkey: 25 Year Analysis. J Forensic Res 8: 388. doi: $10.4172 / 2157-7145.1000388$

Page 5 of 5

11. Ojima T, Nakamura Y, Detels R (2004) Comparative study about methods of suicide between Japan and the United States. J Epidemiol 14: 187-192.

12. Zerbini T, Ponce Jde C, Mayumi Sinagawa D, Barbosa Cintra R, Munoz $\mathrm{DR}$, et al. (2012) Blood alcohol levels in suicide by hanging cases in the state of Sao Paulo, Brazil. J Forensic Leg Med 19: 294-296.

13. Monsef Kasmaee V, Zohrevandi B, Asadi P, Shakouri N (2015) NonJudicial hanging in guilan province, Iran Between 2011 And 2013. Emerg (Tehran) 3:155-158.

14. Starkuviene S, Kalediene R, Petrauskiene J (2006) Epidemic of suicide by hanging in Lithuania: Does socio-demographic status matter? Public Health 120: 769-775.

15. Brock A, Griffiths C (2003) Trends in suicide by method in England and Wales, 1979 to 2001. Health Stat Q 20: 7-17.

16. Gunnell D, Bennewith O, Hawton K, Simkin S, Kapur N (2005 ) The epidemiology and prevention of suicide by hanging: A systematic review. Int J Epidemiol 34: 433-442.

17. Taktak S, Kumral B, Unsal A, Ozdes T, Buyuk Y et al. (2015) Suicidal hanging in Istanbul, Turkey: 1979-2012 Autopsy results. J Forensic Leg Med 33: 44-49.

18. Al Madni OM, Kharoshah MA, Zaki MK, Ghaleb SS (2010) Hanging deaths in Dammam, Kingdom of Saudi Arabia. J Forensic Leg Med 17: 265-268.

19. Verma SK, Lal S (2006) Strangulation deaths during 1993-2002 in East Delhi (India) Leg Med (Tokyo) 8: 1-4.

20. James R, Silcocks P (1992) Suicidal hanging in Cardiff a 15 year retrospective study. Forensic Sci Int 52:167-175.

21. Sauvageau A, Godin A, Desnoyers S, Kremer C (2009) Six year retrospective study of suicidal hangings: Determination of the pattern of limb lesion induced by body responses to asphyxia by hanging. J Foren Sci 54:1089-1092.

22. Abd-Elwahab Hassan D, Ghaleb SS, Kotb H, Agamy M, Kharoshah M (2013) Suicidal hanging in Kuwait: Retrospective analysis of cases from 2010 to 2012. J Forensic Leg Med 20:1118-1221.

23. Sharma BR, Harish D, Sharma A, Sharma S, Singh H (2008) Injuries to neck structures in death due to construction of neck, with a special references to hanging. J Foren Leg Med 15: 298-305.

24. Khokhlov VD ( 2015) Trauma to the hyoid bone and laryngeal cartilages in hanging: Review of forensic research series since 1856. Leg Med (Tokyo) 17:17-23.

25. Jayaprakash S, Sreekumari K (2012 ) Pattern of injuries to neck structures in hanging-an autopsy study. Am J Forensic Med Pathol 33: 395-399.

26. Suarez-Penaranda JM, Alvarez T, Miguens X, Rodriguez-Calvo MS, de Abajo BL, et al. (2008) Characterization of lesions in hanging deaths. J Forensic Sci. May 53: 720-723.
27. Kanamüller J, Riipinen P, Riala K, Paloneva E, Hakko H (2016) Hanging suicides in northern Finland: A descriptive epidemiological study. Death Stud 40: 205-210.

28. San Nicolas AC, Lemos NP (2015) Toxicology findings in cases of hanging in the city and county of San Francisco over the 3-year period from 2011 to 2013. Forensic Sci Int 255: 146-155.

29. Zupanc T, Agius M, Paska AV, Pregelj P (2013) Blood alcohol concentration of suicide victims by partial hanging. J Forensic Leg Med 20: 976-979.

30. Rao D (2016) An autopsy study of death due to suicidal hanging 264 cases. Egyptian J Forensic Sci 6: 248-254.

31. www.tuik.gov.tr/PreHaberBultenleri.do?id=21516

32. Mohanty S, Sahu G, Mohanty MK, Patnaik M (2007) Suicide in India: A four year retrospective study. J Forensic Leg Med 14:185-189.

33. Kinyanda E, Wamala D, Musisi S, Hjelmeland H (2011) Suicide in urban Kampala, Uganda: a preliminary exploration. Afr Health Sci 11: 219-227.

34. Suicide Statistics. Turkish Statistical Institute Publications, Ankara, Turkey.

35. Kurtulus A, Yonguc GN, Boz B, Acar K (2013) Anatomopathological findings in hangings: A retrospective autopsy study. Med Sci Law 53: 80-84.

36. Gören S, Tiraşçı Y, Üzün İ (2005) Retrospective evaluation of the deaths due to hanging in Diyarbakır. Turkiye Klinikleri J Foren Med 2: 1-4.

37. Dean DE, Kohler LJ, Sterbenz GC, Gillespie PJ, Gonzaga NS, et al. (2012) Observed characteristics of suicidal hangings: An 11-year retrospective review. J Forensic Sci 57:1226-1230.

38. Bastia BK, Kar N (2009) A psychological autopsy study of suicidal hanging from Cuttack, India: Focus on stressful life situations. Arch Suicide Res 13:100-104.

39. Ambade VN, Kolpe D, Tumram N, Meshram S, Pawar M, et al. (2015) Characteristic features of hanging: A study in Rural District of Central India. J Forensic Sci 60:1216-1223.

40. Cooke CT, Cadden GA, Margolius KA (1995) Death by hanging in Western Australia. Pathology 27: 268-272.

41. Shivaramu M, Kumar K (2015) Analysis of hainngg cases-a retrospective post-mortem study. MedBio 1: 19-22.

42. Aydın B, Turla A, Boz H, Karaarslan B (2006) Hanging death in samsun. The Bulletin of Legal Medicine 11: 23-29.

43. Demirci S, Dogan KH, Erkol Z, Gunaydın G (2009) Ligature strangulation deaths in the province of Konya (Turkey). J Foren Leg Med 16: $248-252$. 